International Journal of Child, Youth and Family Studies (2013) 3.1: 444-463

\title{
“DU CARRÉ ROUGE AUX CASSEROLES": A CONTEXT FOR YOUTH-ADULT PARTNERSHIP IN THE QUÉBEC STUDENT MOVEMENT
}

\section{Natasha Blanchet-Cohen, Alan Warner, Giulietta Di Mambro, and Christophe Bedeaux}

\begin{abstract}
This article utilizes duoethnography, a collaborative research methodology, to examine the divergent experiences of students and professors in the 2012 Québec student movement. Ignited by the government's announcement of its intention to increase tuition fees, this youth-led movement caused an unprecedented stirring of ideas, emotions, and actions. Through personal narratives, we identify four aspects of a youth-led movement for social change, and reflect on their meaning in our lives in realizing youth-adult partnerships in the context of emancipatory approaches. They are: (a) the benefit of experiential versus classroom education; (b) the nurturing effect on youth empowerment of providing structures and spaces for youth-led processes; (c) the need to align youth emancipatory theory with practice, especially in systems which regularly resist change; and (d) the unexpectedly powerful impact of youth stereotypes, especially those delivered through mainstream media, and the difficulty of overcoming them. We also identify the value of duoethnography to accentuate youth voices, strengthen adult-youth partnerships, and enrich the transformative learning of both youth and adults.
\end{abstract}

Keywords: emancipatory approach, youth-led, movement, adult-youth partnership, student

Natasha Blanchet-Cohen, Ph.D. (the corresponding author) is an Assistant Professor in the Department of Applied Human Sciences at Concordia University, 7141 Sherbrooke Street West, Montréal, Québec. E-mail: natasha.blanchet-cohen@concordia.ca

Alan Warner, Ph.D. is an Associate Professor in Community Development at Acadia University, Wolfville, Nova Scotia. E-mail: alan.warner@acadiau.ca

Giulietta Di Mambro is a student in translation at Concordia University. E-mail: giulietta.di.mambro@gmail.com

Christophe Bedeaux is a student in the Department of Applied Human Sciences at Concordia University. E-mail: c_bedeau@live.concordia.ca 
International Journal of Child, Youth and Family Studies (2013) 3.1: 444-463

You write about our anger, and yes, we are angry. We are angry at our government, at our police and at you. But none of you are [sic] succeeding in conveying what it feels like when you walk down the streets of Montréal right now, which is, for me at least, an overwhelming sense of joy and togetherness. ... I have lived in my neighbourhood for five years now, and this is the most I have ever felt a part of the community; the lasting impact that these protests will have on how people relate to each other in the city is deep and incredible. (Translating the Printemps Érable, 2012, An Open Letter to the Mainstream English Media, paras. 3 \& 5)

In 2012, against a sociocultural landscape in which young people are often portrayed as alienated, self-interested, and financially focused (Gauthier, 2003), North America experienced its largest youth-led movement and engaged social protest since the 1960s (Hallward, 2012). Dubbed the "Maple Spring” by the media, the Québec student movement was sparked by the provincial government's announcement that it would increase university tuition fees by $82 \%$ over a 5-year period (Sorochan, 2012). Encompassing a broad and deep social agenda that went well beyond the fight against the tuition increase, the movement saw students disturbing the peace by striking and marching through the streets over a 10-month period. They mobilized large numbers of people using a wide and sophisticated range of techniques, including participatory education, direct democracy, and civic protest strategies, which were poignantly symbolized by the red square (carré rouge) and the banging of pots (casseroles). The movement impacted the fabric of communities, captivated a society, and contributed to the electoral defeat of the government (Clibbon, 2012; Seymour, 2012). We sensed the opportunity to better comprehend emancipatory approaches in the context of youth-led social movements.

Using duoethnography (Norris \& Sawyer, 2012), a collaborative research methodology, in this article we each recount our experiences of the movement and the lessons we learned. As students and professors positioned in different social and cultural locations, our narratives illustrate how the same phenomena can provide different and important experiences and conclusions about youth-adult partnerships as related to emancipatory practice. Drawing from our personal experiences, we collectively identify aspects that can facilitate youth-led movements that lead to social change. First, we describe our method of inquiry.

\section{Our Method of Inquiry}

This article originated from informal conversations that took place at the June 2012 conference “Transforming Practices: Emancipatory Approaches to Youth Engagement” in Montréal during the peak of the movement. While not formally addressed in the conference program, the student movement was very present in discussions. Initially, the conversations arose among the authors from the desire to understand why student views of the protests seemed different from what was presented in the anglophone media. The students were motivated by the opportunity to explain their experiences in light of what they perceived as misrepresentation in wider society, and the relevance of those experiences to the conference theme. 
International Journal of Child, Youth and Family Studies (2013) 3.1: 444-463

We chose to write a joint article using duoethnography; we were coming together having experienced a common phenomenon (i.e., the movement) but from different locations (Norris \& Sawyer, 2012). In supporting multiple perspectives, rather than accepting one authoritative or powerful voice, we thought duoethnography would bring fresh perspectives and deeper understanding to a youth movement that had disrupted Québec society, and garnered international support (Bherer \& Dufour, 2012).

Our collaboration took shape over a 7-month period, in which we engaged in eight Skype and face-to-face conversations as a group, and numerous one-on-one interactions to share and deepen our own understandings of our experiences by juxtaposing our varied views. Consistent with duoethnography, existing theory from the literature is blended into our sections, helping us give meaning to our experiences.

At the outset we considered writing the article in dialogue format as is conventional in duoethnography (Norris \& Sawyer, 2012). However, the student movement was so complex and our experiences so distinct that we chose instead to write in the first person about our experiences of and thinking on the student movement in separate sections. As we worked through the writing process, we gained a deep respect for each others' experiences, culminating in our decision to collectively write the implications to the conceptualization of emancipatory practice.

\section{Our Distinct Experiences of the Movement}

The four narratives presented below draw on our different social and cultural locations. Giulietta begins by describing her experiences as a francophone student organizer at the heart of the student protest. Christophe then shares his views as an undergraduate francophone student who, though not a student activist, was gradually drawn into the movement through friends and social media. Natasha follows with her perspective as a bilingual university professor in Montréal, whose work focuses on youth engagement. Finally, Alan reflects on his experience of the movement as an anglophone university professor based in Nova Scotia. Each of us identified learnings that emerged from our reflections.

\section{Transformative Education in the Streets: A Student Activist's Perspective}

Giulietta: I approached the 2012 student strike with prudent hope, though I had felt alienated by the rise and fall of previous movements. My involvement started on March 6, when the executive committee of the Concordia Graduate Student Association (CGSA) convened a General Assembly (GA) to discuss the possibility of going on strike.

I attended, considering this my duty as a graduate student. An astounding 600 or 700 students showed up. Three hours later, we achieved a first in Québec history: an anglophone institution of higher learning voting in favour of an unlimited strike mandate, and supporting a motion to become affiliated with CLASSE (Coalition Large de l'Association pour une Solidarité Syndicale Étudiante), the most radical provincial student organization. This sparked my interest and filled me with a great sense of hope because historically, Québec student activism had been a 
International Journal of Child, Youth and Family Studies (2013) 3.1: 444-463

typically francophone effort. I was excited by my peers' courage: By choosing to officially voice their dissent and join the general strike, Concordia students were transcending the perceived lack of will for communication between Québec anglophones and francophones, replacing the "two solitudes” with solidarity.

Discovering meaningful "university" education. I quickly realized that there was a discrepancy between the students who participated in the first strike-oriented GA, and the rest of the student body. The democratic culture was absent from Concordia's institutional ethos. My political self and my passion for education came together; I had a reason to act. Concordia students were taking baby steps in direct democracy, but there was also much ambiguity. My first reflex was to write a letter explaining my position and reasons to strike, which I sent to faculty members in my department, as well as some student peers. I received deprecating comments from some professors, and encouragement from others. From that moment, there was no going back, and things started to snowball. I participated in recruiting and motivating students to go to their general assemblies, through class announcements as well as informal discussions on campus.

I had mixed feelings about my peers' ignorance of the issues: Do we not all cherish our democratic values? I actively participated in weekly GAs giving my opinion and voting in favour of extending our unlimited strike motion. These official gatherings - chaired by students, all versed in Robert's Rules of Order and gender equity - ensured that respect for differences of opinion was maintained throughout the decision-making process. GAs were a non-threatening space with high pedagogical value that clarified and reiterated what it meant to be on strike, how striking works, and the reasons for striking, while justifying tactics like picket lines and what actions to take.

As an additional obstacle, picket lines were severely repressed at Concordia, with the administration hiring security guards from private firms mandated to intimidate students on picket lines. Several times, security guards tried to force me to identify myself and threatened to call the police if I did not stop participating in the picket. The Concordia Graduate Student Association (CGSA) denounced this type of behaviour, especially when a security guard on university grounds struck a woman student on the head. My worst picketing memory was seeing a tall education professor push my friend and look down on her in an intimidating fashion so as to make way for his students to enter his classroom, thus disrespecting the strike mandate.

As a multilingual student studying translation, the opportunity to facilitate solidarity between francophone and anglophone cultural groups further catalyzed my motivation to act. I realized I could put my linguistic talents to use for the cause. Working with two other students, we created the RougeSquad ${ }^{1}$, a volunteer-based translation group dedicated to diffusing francophone news about the strike to English speakers, and to responding to the English mainstream media's biased portrayal of the movement. In a week, we had recruited a group of loosely affiliated volunteer members, working in teams, translating and posting on the website.

${ }^{1}$ http://rougesquad.org/ 
International Journal of Child, Youth and Family Studies (2013) 3.1: 444-463

This is what I had imagined university would be - an intellectually creative space for sharing across disciplines and institutions. It was unprecedented in my long university student experience.

The large, ongoing street protests coupled with GA participation gave me a feeling of belonging to a political community, and of being able to explore a shared vision of society, while collectively confirming my political identity. Indeed, a whole vision of society was emerging from this movement, which was vastly underrepresented in mainstream media coverage. These protests did not revolve around the monetary aspects of a tuition increase, but rather the symbolic meaning of this tuition increase and its implications on governance. I realized that the most valuable "university" education came through dialogue, personal involvement in community building, and leadership in the streets.

The potential of youth-led, direct democracy. My participation intensified when I was elected as an Arts and Science representative to the Concordia Graduate Student Assembly (CGSA). In addition to participating and mobilizing for local GAs, I volunteered to act as Concordia's graduate delegate to CLASSE congresses. This was the ultimate in direct democracy, where representatives of over 50 affiliated student groups came together on a weekly or bimonthly basis to share and brainstorm about specific issues, and put forward motions that had been voted for in their own local assemblies in order to give direction to CLASSE's overall position in the conflict.

I was stunned by the quality and professionalism of student interventions. In the past, the leading student groups had always been the provincial federations, which functioned by representative democracy. Local student associations entrusted provincial representatives to make the right calls during negotiations with government, with no obligation for the representatives to get agreement from their base before "sealing the deal" with government officials. The unprecedented ascension of CLASSE as a leading force in the 2012 strike unveiled the powerful potential of grassroots movements. For the first time in Québec history, the leading provincial student union was functioning by direct democracy, which meant the student base, and not its leaders, would decide the strike's outcomes.

CLASSE's priority was to empower and educate its members using direct democracy (Beaumont, 2012). As of 2010, part of CLASSE's strategy had been to create and offer a wide range of tools to help mobilize and stimulate its base. This involved training camps with workshops on the principles and foundations of political action, effective strikes, how to coordinate a GA, effective meeting and decision-making procedures, among other topics. For younger students in CEGEP (post-secondary college prior to university), campus mobilization campaigns were supported by CLASSE through “job-shadowing” and mentoring experiences, linking each campus association to an assigned mobilization agent. There were tremendous opportunities for informal learning. The outcomes speak to the strength of peer-led and peerinitiated education for youth, by youth.

Applying direct democracy as the core value meant there was no hierarchy. As a CGSA delegate, my voting powers were dictated and strictly circumscribed by motions passed in our own association: I was representing a collective voice. In the same manner, I loved the fact that 
Gabriel Nadeau Dubois, CLASSE's main spokesperson, was given neither special treatment nor status during CLASSE congresses. His interventions were in the name of his local association, nothing more. I was especially inspired by the verve of younger students' interventions, which reminded me of why I wanted to be an educator. These youth were not only passionate and extremely articulate, they were also more at ease with organizational processes than I was, and the motions they brought forward showed a holistic understanding of the situation and a high level of critical consciousness. The potential of youth-led, direct democracy for facilitating individual learning and effective collective action was my second enduring lesson.

Experiencing repression. In mid-April, after dozens of protests and press conferences inviting dialogue, the government had not budged. Escalation was seen as a last resort to catalyze resolution, and I believe that the direct actions had a significant role to play in the government's decision to finally open dialogue with the students. At this point, the only way to have our voices heard was by disrupting the only thing that seemed to matter in the neo-liberal paradigm: economic activity.

Unlike other post-secondary institutions, Concordia's administration ignored the protests and held final exams as scheduled, even though entire departments had been on strike for six weeks. On the first day of exams, I joined the picket line in which students from many institutions formed a human chain around the university. The university response was to call in riot police to remove us by force. The squadron charged us, advancing at a brisk military pace as they intimidatingly banged their batons on their shields. They did not stop until we were practically belly-to-belly and I could see the nervous sweat pearl on their visors. We chanted: "Les enfants des policiers sont aussi des étudiants!"

I was on the front line in solidarity with my peers, linking arms and refusing to step back. The only thing separating us from their heavily-armed attire was our cloth banner marked with demands for truly accessible education and transparent governance. My chants were muted by the sting of a police shield striking my upper jaw, sending searing pain to my brain. Batons were whipped against my shins, bringing me to my knees, followed by a shower of tear gas sprayed into my eyes from 30 centimetres away. My exposed skin and lungs were on fire. Students by my side were kicked to the ground.

We were doing this for future generations, including the children of these police officers, but they had clear orders. They made no exceptions even for the physically disabled students in the group, one of whom I saw pushed off balance and held to the ground by a police officer. At that moment, I felt ashamed to be Canadian. How could student dissent be repressed as though it were a crime, when we supposedly built this country on democratic values? The tears in my eyes were stimulated by a physiological reaction to the tear gas, mixed with feelings of sheer frustration and impotence. By bruising my bones, they intended to break my dreams. They did not break my self-control despite the injustice - none of us retaliated with violence.

This incident was the source of direct albeit painful experiential learning on the limits of liberal democracy and the brutality of state power. Even though the strike was a vehicle for youth to create a social context in which we could be collectively heard, using direct democracy 
International Journal of Child, Youth and Family Studies (2013) 3.1: 444-463

as a means and an end to promote progressive values, youth were continually and consistently infantilized, criminalized, and brutalized by the state and mainstream media. This was a powerful third lesson.

The baton bruises and stinging tear gas were all worth sustaining. They brought to light the mechanisms of power that depicted youth as violent while applying severely repressive tactics to contain dissent. A tremendous sense of satisfaction arose from the fact that our actions, while characterized as "violent" by the mainstream media, made the mask fall, albeit momentarily, shaking up our political landscape and bringing humanist values to the forefront.

\section{From Awareness to Involvement to Confrontation: A Reflective Student's Perspective}

Christophe: During the student protests, I was an undergraduate francophone student in Psychology and Human Relations at Concordia University. Unlike Giulietta, I was not as directly involved in the student movement, but became pulled into it. My department did not vote for a strike mandate, nor was there much discussion about the student movement. Instead, I became informed through friends from francophone universities who explained the reasons for the demonstrations and invited me to join them. Social media, particularly Facebook, also played a critical role in helping me access information shared by students, teachers, and supportive organizations. I discovered research on-line, posted by students, debunking the arguments used by the Liberal government to support the tuition hike. This information played a crucial role in convincing me of the legitimacy of the movement and the unacceptability of the tuition increase.

My participation in this movement had significant impacts on my perception of society. Participating in demonstrations involving more than 200,000 people gave me a strong sense of belonging. I experienced a sort of transcendence: belonging to and participating in something way bigger than myself. This feeling is the antithesis of the mainstream media judgment that student protesters were egocentric. This movement was a time when, for protesters, the collective was more important than the individual. This experience strengthened my identity as a French Québécois and I felt I was participating in an important piece of Québec’s history. Simultaneously, I felt more alienated from other social groups who were either not involved or opposing the movement. My experience deepened my awareness of the role of social media and the troubling repression and brutality by police. Below, I discuss these transformational issues, drawing both on my experience and research.

The contribution of social and student media. The movement influenced me to place more trust and value on social media, and to more critically examine the portrayal of the student protesters and their organizations conveyed in the media and by the government. I observed that the government was trying to marginalize and devalue the students by portraying them as violent. The mass media disseminated videos showing provocative and uncivilized acts from protesters, but rarely showing the violence and brutality of police repression. Having a background in social psychology, I disapproved of targeting and degrading people to justify a political decision.

In response, I read and watched social and student media to gain a broader and more accurate view of the conflict. They played a critical role in enabling student organizations to 
International Journal of Child, Youth and Family Studies (2013) 3.1: 444-463

mobilize students for events and communicate positions thoughtfully. Two key outlets were Concordia University TV (CUTV), an on-line television channel, which was most prominent, and social media such as Facebook and Twitter (Wyatt, 2012).

One of the main strengths of student media was that, by being inside the conflict, they were able to cover events more intensively, deeply, and directly than traditional media (DallaireFerland, 2012; Therrien, 2012). CUTV attracted up to 100,000 viewers a day and also relayed information from student organizations to more traditional media. One challenge faced by student media was that student journalists did not benefit from the same privileges as traditional media. Several student journalists were arrested or intimidated despite showing their press passes (Dallaire-Ferland, 2012; Therrien, 2012). In spite of this, videos filmed by these journalists were shared widely with significant impact. One video ${ }^{2}$ showing a police officer shouting, "There! Right in the ass, y'little shit” at a protester after having fired a rubber bullet at him, had more than 225,000 views.

Facebook and Twitter also played a vital role in facilitating coordination and communication between students and in reaching out to the broader public. Facebook events were created for each protest, and news, pamphlets, and posters were shared (Radio-Canada, 2012; Wyatt, 2012). A cyber protest was organized on Twitter. Internet and social media were used to relay the students' messages and arguments to the population and to respond to the government's messages, without necessarily requiring a spokesperson, and at low cost. A good example of the creative use of the Internet was the development by students of a bilingual website explaining the arguments against the tuition hike, mirroring the one created by the government (which cost $\$ 50,000$ ) to support the tuition hike. Another powerful communication tool was the creation of two websites, Translating the printemps érable ${ }^{3}$ and RougeSquad offering English translations of francophone media articles in order to reach the anglophone population, as mentioned by Giulietta.

A study surveying social media conversations related to the student protest during May 2012 found that social media were occupied mainly by student protesters and their organizations, whereas government outlets were relatively absent, with the exception of the Montréal Police (Sciencetech Communications, 2012). This study further noted that students and their organizations did not use a formal communication strategy on social media. Instead, they improvised and did not require additional expertise because students use social media naturally.

The lessons of police brutality. Another way in which this movement transformed me involved the state and police response. I had heard about police brutality and social and racial profiling, but here I actually experienced it. I was struck when police anti-riot squads charged firing rubber bullets, not discriminating between protesters who were peacefully demonstrating and those who were not. Witnessing the brutality and repression decreased my trust in the Montréal and Québec police.

${ }^{2}$ http://youtu.be/rKWJ1la45P4

${ }^{3}$ http://translatingtheprintempserable.tumblr.com/ 
International Journal of Child, Youth and Family Studies (2013) 3.1: 444-463

A total of 3,387 people were arrested at protests between February and September (Dupuis-Déri, 2012). One hundred and ninety-three complaints were made to the Commissaire à la Déontologie Policière du Québec, Québec’s police ethics commissioner (D’Astous, 2012). Additionally, a request for a public enquiry on police repression was made by about 30 organizations in Québec, including a collective of teachers and professors, Amnesty International, and the League of Rights and Liberties (Dupuis-Déri, 2012). The Montréal police force was accused of having violated human rights through arbitrary mass arrests and detentions, social profiling, and abusive body searches, and by not providing first aid to injured protesters. They were reported to be using disproportionate levels of force against protesters resulting in some serious injuries (Dupuis-Déri, 2012; Profs contre la hausse, 2012). They were also accused of prejudice and contempt against the protesting students and people wearing the red square (Jutras, 2012).

This repression has affected me and numerous other protesters and students who have become fearful of the police. Some have told me that the goal was to scare protesters away from the demonstrations and decrease the movement's strength. Indeed, it affected me. I started to feel unsafe and scared of being injured or arbitrarily arrested during demonstrations after having experienced and/or watched on video riot police charging protesters, dousing them with pepper spray, hitting them with riot batons, and shooting them with rubber bullets. I stopped going to night demonstrations, or left early. I believe that one consequence of police repression and brutality was to scare away the most peaceful protesters and to motivate the hard core, which in turn increased the risk of tension and violence. The heavy presence of riot police, separating protesters, and blocking streets during demonstrations acted as antagonizing factors for protesters, rather than pacifying them (Marshall, 2012).

This student movement was for me a wake-up call that engendered a strong desire to participate in issues that affect me. It brought to the fore creativity and new ideas, and influenced me to take advantage of opportunities offered by social media. It illuminated for me the resistance to the repression of the government and the brutality of police forces.

\section{Facilitating Youth Rights and Youth-Led Movements: A Bilingual Professor's Perspective}

Natasha: As a university professor at Concordia and a parent of young children, my experience was very different from that of either student. Though living in Montréal and teaching community development, I only became attentive to the student movement on March 22. Given that the university had cancelled classes, I had organized research meetings for that day. Returning home by the Montréal Metro, I saw young people with red placards flood into the cars. There was a thrilling feeling in the air and I decided to see for myself. The number of people and the energy overtaking the streets stunned me. Certainly 20 years ago, I would have been fully involved. But here I was an observer, somewhat uncomfortable given my position as a professor employed by a university that had requested faculty to "fulfil their current duties and responsibilities” (David Graham, personal communication, March 6, 2012). I somewhat envied the youth's courage and passion. 
International Journal of Child, Youth and Family Studies (2013) 3.1: 444-463

I returned to work and social activities with a newfound interest in talking about the movement. This was not a neutral topic. Conversations with parents of my children's friends as we waited for swimming classes showed me the contempt and criticism adults had for the youth who were taking to the streets. Parents emphasized youth's responsibility to do their share; no mention was made of youth's fresh perspectives, perseverance, and innovative strategies. I tried to refrain from being judgmental.

I realized that this was about youth engagement in community, a subject I have researched for the past 15 years. Youth were fully invested, employing their energy and competencies as well as engaging other members of the community (Villarruel, Perkins, Borden, \& Keith, 2003). It was a collective effort by young people to ensure social justice for youth at a scale that I had never witnessed. Its potential for community change was inspiring compared to single youth-led programs (Blanchet-Cohen \& Cook, 2012). I needed to engage with what was happening in my backyard.

My contribution was to conduct research that gave voice to the youth who daily took to the streets despite the criticism and risks. The decision reflected my responsibility as a researcher to be an agent of social change. Generating and sharing knowledge were, after all, another means of giving power to youth. Several authors have also called for more empirical research on youth engagement in community settings to inform practice (Checkoway \& Gutierrez, 2006; Zeldin, Camino, \& Calvert, 2007). I put other work on the back burner to focus on the movement. I began doing interviews and focus groups with youth under the age of 18 to understand the reasons for their involvement, how they pressured government despite their status as minors, and how they perceived the state as the primary duty bearer responsible for young people's right to participate (Blanchet-Cohen, 2013).

Youth rights and participation: The gap between theory and practice. One key realization from my experiences of the student movement was seeing the gap between the glorified international discourse on youth's right to participate and society's openness to it. Legally, according to the United Nations (1989), young people may have the right to "express their views” (United Nations Convention on the Rights of the Child [UNCRC], Article 12), to freedom of association (UNCRC, Article 15), and to the freedom to access appropriate information (UNCRC, Article 17), but in reality there was a discomfort with young people's political participation. Participation was promoted for youth development up to the point where young people disobeyed rules and questioned decisions made by adults in power. Young people's rights were easily forfeited when young people trespassed on adults' notions of good citizenship behaviour. It was a reminder of the paradoxical perspective of established interests with respect to youth: Youth agency can be profiled when contributing to the status quo, but is repressed when opposing dominant discourses (Wyn \& White, 2000). Of significance in this instance is that despite the repression and criticism, young people persevered, succeeding in revoking the announced student fee hike and changing the political landscape.

Creating space and involving allies. A second aspect that stood out involved the role of space and allies in facilitating the youth-led movement. Frequently, student groups are unstable because leadership rotates quickly, resulting in a loss of accumulated knowledge and 
competencies in the process. Student organizations in Québec have, however, a social and cultural history that is unique in Canada (Gauthier, 2003). Analysis of the Québec movement shows that knowledge has not been lost, but rather reinvested, transferred, and documented from one strike experience to another (Choudry, 2012). Student organizers have also institutionalized their learning through the creation of provincial associations that act as centralizing bodies for coordinating local association mobilization strategies, playing an active role in transmitting and maintaining their capacities. Funded through student fees, universities and government have paradoxically and implicitly contributed to building these organizations. Indeed, the structure and resources for youth-led organization provided a "space for youth participation and social recognition attached to it”, two critical elements of youth engagement identified by Harré (2007, p. 714).

Beyond society's provision of space for youth organization, an additional positive factor for the movement was the support it received from adult allies. Although the movement was youth-led, its success was fundamentally assisted by support from adult organizations across Québec. In particular, the movement was invigorated by the government's move to halt the protests and civic unrest by passing Law 12 (Seymour, 2012). Recognizing the new law as a threat to democratic rights, other prominent social groups such as lawyers, judges, unions, and university faculty came out in strong support of the student movement. Now the rights of every citizen were under attack. The shared feeling of conflict with government represented a key ingredient in facilitating a sense of unity and belonging among the young people (Harré, 2007). Adult support was necessary to provide for broader social change, but the power of the movement remained with the youth (Wong, Zimmerman, \& Parker, 2010).

\section{Shifting Views: A Professor's Perspective from English Canada}

Alan: As an anglophone professor at a rural university in Nova Scotia, I experienced the movement differently from Giulietta and Christophe as well as Natasha. During the first seven months of the protests, I was on sabbatical in New Zealand. I had only heard of the student protests in March when violent incidents were reported in the international media. I had been back for just three weeks when I came to Montréal for the international conference on youth engagement. During those three weeks, I had been bombarded on a daily basis by the English Canadian media with news reports about the protests. The tuition issue was typically framed in relation to the fact that Québec students already paid the lowest fees in Canada and the increases would only raise tuition to the national average (Dehaas, 2012; Simpson, 2012). The student protesters were presented as young, egocentric troublemakers who did not recognize their privilege and the considerable subsidy they were receiving from taxpayers. The violent actions were presented as threatening the viability and reputation of Montréal as a tourist destination, and the economic benefits that would flow from that industry. There was little discussion of the issue on my university campus in Nova Scotia. Most students had left for the summer. Among those remaining, as well as among faculty and staff, there was little support for Québec students given that Nova Scotia's students had been swallowing tuition increases on a yearly basis for the last decade. 
International Journal of Child, Youth and Family Studies (2013) 3.1: 444-463

Building identity and community through experiential learning. I arrived in Montréal with this perspective. However, it was radically altered over the course of a few days based on extended conversations, particularly with the student co-authors of this article. Ultimately, I marched one afternoon with several thousand others banging pots through the streets of Montréal. I experienced the protests from a youthful, street perspective, and was moved by the support of those people lining the sidewalks and balconies along the route, and banging pots in response. It gave me an inkling of the collective sense of belonging experienced by the students.

My perspective on the protests shifted radically and I came to see them as a fascinating example of successful youth engagement that was challenging government and neo-liberal interests and priorities. Large numbers of young people were demonstrating in an unparalleled and persistent effort, as well as organizing large-scale and non-violent civil disobedience to bring about social change. This came at a high personal cost to their formal educational aspirations and economic self-interest. The personal tuition increases for those protesting were small relative to the time spent in the streets and the expense of paid tuition fees that promised no course credits in the wake of the extended strike and cancelled classes.

Through my experiences and conversations with students, it was clear that the sense of belonging and collective identity they established were keys to their success and the willingness of so many to persevere despite the personal costs. Niki Harré (2007) argues that community activism among youth is an "identity project" and is more successful when it is characterized by belonging, efficacy, and stimulation, and speaks to core values. The Québec student movement built identity through deliberate participatory and experiential education practiced in the streets. It was not just about getting demands met, but about the education gained through participating in the process. Student organizations supported and enabled young people to actually practice citizenship and build action competence (Jensen \& Schnack, 1997), which has largely been overlooked in formal curricula. Instead, school curricula on citizenship education have mostly dealt with teaching skills, knowledge, and attitudes related to citizenship as "apprenticeship" (Liebel \& Saadi, 2012, p. 177). This narrow focus ignores the fact that young people actively participate in political processes related to their own everyday lives (Thomas, 2009). Community youth development emphasizes the importance of experiential learning to build relationships and a sense of community at a group or program level (Warner, Langlois, \& Dumond, 2010). My first lesson drawn from this student movement was the benefit and possibility of building such a process on a broad scale.

Challenging media narratives and the reinforcement of youth stereotypes. Once in Montréal, I quickly came to see the impact of the media in framing my initial view of the protests and my implicit acceptance of the stereotypes and messaging. This was startling given my self-perception as a critically thinking, media-literate academic with specific expertise in community youth engagement. Upon my return to Nova Scotia, I found myself engaged in many conversations with my colleagues in which I was educating them and rebutting views that I had accepted just a couple of weeks previously.

The mainstream media defaults to the portrayal of youth activism in a stereotypical manner - that is, as the actions of self-indulgent and attention-seeking troublemakers with radical 
elements in pivotal organizing roles (Gilliam \& Bales, 2001). The youth as troublemaker narrative is highlighted with any violent incident, whatever the context. The high profile example for the Maple Spring was the June 4, 2012 cover of Maclean's magazine which portrayed a student with his face covered by a red bandana under the headline: “Québec's new ruling class”. The result is that many adults, who are removed from youth lifestyles and perspectives, implicitly accepted the stereotypes and worried about potential political, social, and economic instability brought about by youth activism (Gilliam \& Bales, 2001; Hampton, Hartmann, Hurley, \& Lamarre, 2012). The student co-authors describe the organizational and contextual dynamics that enabled the student movement to combat the media stereotypes in Montréal. Student and social media were essential to reaching out to youth and informing the public. French-language media were more balanced in reporting events and did not consistently communicate the negative perspectives and stereotypes which could be found in English-language media, both in Québec and across Canada (Christoff, 2012; Giroux et al., 2012). Media stereotypes seemed most dominant for those who were most distant from the experience in the streets.

I recognized the need to be vigilant about not allowing my perspectives to be defined by mainstream media, particularly when the phenomena are distant and hard to comprehend. Alternative media sources are essential to understanding a phenomenon. Without them, those removed from the experience are left vulnerable to accepting mainstream media interpretations of events. The student movement was not an instance of feel good, youth volunteerism in which the mainstream media is typically a youth ally, providing images of enthusiastic young people doing positive things for the community. Youth-led activism is not typically portrayed in the same positive vein, particularly when it challenges established community or government institutions and practices. Interestingly, the movement gained positive media attention when respected and powerful adults wearing robes (judges and lawyers) protested Bill 78 (later Law 12), a law passed by the government which restricted freedom of association and assembly and included fines for individuals and student organizations. The law was criticized for infringing on the rights guaranteed in Québec's Charter of Human Rights and Freedoms (Bherer \& Dufour, 2012). In English Canada the media discussion shifted from "What should they do with those spoiled brats?” to "What is actually going on in Québec?” (Somerville, 2012). The latter question prompted some journalists to present more nuanced perspectives, even if superficial criticism of the students still dominated many publications. My second lesson is that established interests attract and drive positive media coverage, and that media coverage is extremely influential in framing social and political issues, even if I might think that I can maintain a critical perspective.

\section{Implications}

Emerging from our accounts of the student movement we identified two implications for emancipatory approaches to youth engagement. The first focuses on the contributions that support youth-led processes and social change, and the second relates to the value of duoethnography as a means to enable youth voices to be meaningfully represented in scholarly work. 
International Journal of Child, Youth and Family Studies (2013) 3.1: 444-463

\section{Youth-Led Movements and Social Change}

While our narratives were distinct, we found interrelationships among our different perspectives. In developing youth-led initiatives for social change, we identified four shared aspects to consider (see Table 1). They are: (a) the benefit of experiential education for both youth and adults; (b) the nurturing effect of structures and spaces to support youth-led processes; (c) the need to align youth emancipatory theory with practice, especially in systems which regularly resist change; and (d) the unexpectedly powerful impact of youth stereotypes, especially those delivered through mainstream media, and the difficulty of overcoming them. Taken as a whole, these suggest that there are both internal and external dimensions to youth-led processes leading to social change that is emancipatory.

\section{Table 1. Aspects of Youth-Led Movements and Social Change}

1. Seeking experiential education for youth and adults Meaningful "university" education is in the streets (Di Mambro)

Building identity and community through experiential learning (Warner)

2. Providing structures and spaces for youth-led processes

The potential of youth-led, direct democracy (Di Mambro)

Creating space and involving allies (Blanchet-Cohen)

3. Resisting systemic responses

Awakening to the system's resistance and police brutality (Bedeaux, Di Mambro, Warner)

Youth rights and participation - the gap between theory and practice (Blanchet-Cohen)

4. Re-appropriating media

The contribution of social and student media (Bedeaux)

Challenging media narratives and the reinforcement of youth stereotypes (Warner)

With respect to the internal dimensions of the movement, our narratives suggest that youth-led processes that allow youth to personally experience the value of collective action can be transformative. This experiential element allowed youth and adults to connect more deeply with the issues, particularly creating a sense of belonging. This finding is consistent with Zeldin, Christens, and Powers (2012) who identify the psychological context as key to realizing youthadult partnerships. This experiential education process arose in part out of the space and structures for youth-led processes that were already present. These structures allowed the impactful relationships to be built internally, as well as externally with allies and the general public (Percy-Smith \& Thomas, 2010).

Another aspect was that in challenging the status quo, youth, and adults who supported the movement, had to confront a system that defended established norms. The level of resistance was illuminating, if not surprising. We found that working through youth-led processes requires building youth-adult partnerships, and fighting against systems that resist youth voices and social justice perspectives. Finally, social media became a key means for youth to communicate among themselves and with the broader public. Its use mirrored the Arab Spring in which digital media 
International Journal of Child, Youth and Family Studies (2013) 3.1: 444-463

was a tool that broadened dissent occurring in specific places, facilitating a collective consciousness and providing an internal means of communication that identified opportunities for joint action (Howard \& Hussain, 2011).

It is interesting to note that within each aspect, we found clear interconnections between the sub-themes although they are expressed and framed differently based on each of our social locations. For experiential education, Giulietta’s passionate first person experience of discovering meaningful education in the streets contrasts in tone with Alan's recognition of similar phenomena based on conversations, program experiences, and academic literature. Yet in both cases the focus on the nature of interaction and direct participation is paramount.

\section{Duoethnography as an Asset in Youth-Adult Partnerships}

Beyond what we learned about youth-led processes that contribute to social change, we found the duoethnography methodology valuable in bringing forth youth voices in ways not possible through other research methods. It might be argued that the adult researchers could have simply interviewed student activists and then analyzed the interviews to generate similar narratives. However, even with appropriate respondent checking in the methodology, we do not believe the result would have been as relevant for multiple reasons.

Duoethnography engaged the youth as researchers, giving space for students' voices, and offering an insider's perspective on what happened. This process allowed us all to come away with a deeper understanding of what defined this youth-led movement and its broader implications. As professors, Natasha and Alan were introduced to a phenomenon through the eyes of the students who experienced it most directly, providing for a deeper appreciation of the movement. As students, Giulietta and Christophe each had very different experiences of the movement, a reminder to be careful not to generalize for either youth or adults.

The method was pedagogical and emancipatory for all of us as authors. Engaging in the conversations and writing process altered and enriched our perspectives, an integral aspect of duoethnography (Sawyer \& Norris, 2012). We discussed, and at times debated, how the stories would be best told. Our dialogue was a reminder that duoethnography involved each one of us undoing historical and cultural scripts (Norris \& Sawyer, 2012). While listening to the passionate and at times gut-wrenching stories of youth in a way that does not typically occur, Natasha and Alan emphasized to Giulietta and Christophe the importance of first-hand experiences in writing, and that citing external sources was not always needed to legitimize their voices. Both Giulietta and Christophe felt that writing was a way of validating the movement.

Having students and professors in an ongoing dialogue across the different stages of conceptualization, writing, and editing allowed us to work through some of our differences and present a more complex and multi-faceted understanding of this phenomenon. Throughout, each of us had to be sensitive to negotiating across our diverse spaces and respecting our individual experiences. The format for our concluding comments was the result of an ongoing dialogue that generated a shared synthesis of our different perspectives. We considered writing the final 
International Journal of Child, Youth and Family Studies (2013) 3.1: 444-463

section in a dialogue format, but through our conversations we realized that we had come to identify common themes, much as a focus group in which consensus is drawn out of discussion. The format was an opportunity for youth and adults to interact in more egalitarian ways, respecting youth voice, which is often lost in the writing process. In the future, it would be interesting to explore duoethnography as a mean of transformative learning for both youth and adults to strengthen adult-youth partnerships in the context of emancipatory approaches.

\section{Concluding Thoughts}

The Québec student movement provides a powerful example and valuable lessons for youth-led civic engagement. Through the movement, youth demonstrated a level of creativity and innovation that stands as an illustration of the effectiveness of young people in contributing to social change when given the means to do so. In enacting direct democracy, using alternative media, resisting the system through non-violent means, and protesting by strategically reaching out to the broader public, young people showed their capacity to facilitate social change. Our use of duoethnography was transformative, uncovering the multi-faceted perspectives and deepening our own understandings of our individual experiences. Privileging individual voices as well as dialogue, and the melding of youth and adult voices may be a useful method for approaching emancipatory approaches to youth engagement on complex social and cultural issues. 
International Journal of Child, Youth and Family Studies (2013) 3.1: 444-463

\section{References}

Beaumont, E. (2012, juin 1). Mon congress de la CLASSE. L'Actualité, 37(9), 22.

Bherer, L., \& Dufour, P. (2012, May 23). Our not-so-friendly northern neighbor, The New York Times. Retrieved from http://www.nytimes.com.

Blanchet-Cohen, N., \& Cook., P. (2012). The transformative power of youth grants: Sparks and ripples of change affecting marginalised youth and their communities. Children \& Society. Advance online publication. doi: 10.1111/j.1099-0860.2012.00473.x

Blanchet-Cohen, N. (2013). The protagonism of youth under 18 in the Québec student movement: The right to political participation and education. In E. Swadener, L. Lundy, J. Habashi, \& N. Blanchet-Cohen (Eds.), Children's rights and education. International perspectives (pp. 63-81). New York: Peter Lang.

Checkoway, B., \& Gutierrez, L. M. (2006). Youth participation and community change. Journal of Community Practice, 14 (1/2), 1-9.

Choudry, A. (2012, Fall). Avec nous dans la rue: Pedagogy of mobilization, university of the streets. Journal of Mobile Media, 6(2). Retrieved from http://wi.mobilities.ca/avec-nousdans-la-rue-pedagogy-of-mobilization-university-of-the-streets/

Christoff, S. (2012, Feb 24). CBC misrepresenting Québec student strike? Retrieved from Coop Média de Montréal website: http://montreal.mediacoop.ca/newsrelease/10031

Clibbon, J. (2012, May 29). How a student uprising is reshaping Québec. Canadian Broadcasting Corporation. Retrieved from http://www.cbc.ca/news/canada/story/2012/05/29/f-quebec-students-voices.html\%20

D’Astous, C. (2012, September 20). 46\% des plaintes contre les policiers rejetées. Le Huffington Post Québec. Retrieved from

Dallaire-Ferland, R. (2012, June 2). The Québec Spring, as seen by student media. (Translating the printemps érable, Trans.). Retrieved from Translating the printemps érable website: http://translatingtheprintempserable.tumblr.com/post/24382286163/the-quebec-spring-asseen-by-student-media-le-devoir

Dehaas, J. (2012, May 7). Why I'm skeptical of the tentative deal in Québec. Maclean's On Campus. Retrieved from http://oncampus.macleans.ca/education/2012/05/07/why-imskeptical-of-the-tentative-deal-in-quebec/\#more-39708 
International Journal of Child, Youth and Family Studies (2013) 3.1: 444-463

Dupuis-Déri, F. (2012, September 25). Student movement and police repression - For a commission of public inquiry. (Translating the printemps érable, Trans.). Retrieved from Translating the printemps érable website:

http://translatingtheprintempserable.tumblr.com/post/32272398855/student-movementand-police-repression-for-a

Gauthier, M. (2003). The inadequacy of concepts: The rise of youth interest in civic participation in Québec. Journal of Youth Studies, 6(3), 265-276.

Giroux, D., Charlton, S., Bouchard, O., Dayé, M-A., Mercier E., \& St-Pierre, M. (2012, November). Les journaux ont-ils été plus critiques à l'égard d'un camp? Presentation at Le Congrès de la Fédération professionnelle des journalistes du Québec, Saint-Saveur, Québec. Retrieved from http://www.cem.ulaval.ca/pdf/FPJQ17nov2012.pdf

Gilliam, Jr., F. D., \& Bales, S. N. (2001). Strategic frame analysis: Reframing America's youth. UC Los Angeles: Center for Communications and Community. Retrieved from http://www.escholarship.org/uc/item/5sk7r6gk Harré, N. (2007). Community service or activism as an identity project for youth. Journal of Community Psychology, 35(6), 711724. doi: 10.1002/jcop.20174

Hallward, P. (2012, June 1). Quebec's student protesters give UK activists a lesson. The Guardian. Retrieved from http://www.guardian.co.uk

Hampton, R., Hartman, M., Hurley, A., \& Lamarre, R. (2012, Fall). Fear and violence in Québec: Why solidarity with a diversity of tactics matters. Journal of Mobile Media, 6(2). Retrieved from http://wi.mobilities.ca/fear-and-violence-in-quebec-why-solidarity-witha-diversity-of-tactics-matters/

Harré, N. (2007). Community service or activism as an identity project for youth. Journal of Community Psychology, 35(6), 711-724. doi: 10.1002/jcop.20174

Howard, P., \& Hussain, M. (2011). The role of digital media. Journal of Democracy, 22(3). 3548. doi: 10.1353/jod.2011.0041

Jensen, B., \& Schnack, K. (1997). The action competence approach in environmental education. Environmental Education Research, 3(2), 167-178.

Jutras, B. (2012, June 2). Conflit étudiant - La poésie de la police. Le Devoir. Retrieved from http://www.ledevoir.com/societe/actualites-en-societe/351469/la-poesie-de-la-police

La Ligue des droits et libertés, l'Association des juristes progressistes, and l'Association pour une solidarité syndicale étudiante. (2013). Rapport : Répression, discrimination et grève étudiante: analyses et témoignages. Retrieved from

http://www.fspd.uqam.ca/upload/files/rapport-2013-repression-discrimination-et-greveetudiante.pdf 
International Journal of Child, Youth and Family Studies (2013) 3.1: 444-463

Liebel, M., \& Saadi, I. (2012). Cultural variations in constructions of children's participation. In M. Liebel (Ed.), Children's rights from below. Cross-cultural perspectives (pp. 162-174). New York: Palgrave Macmillan.

Marshall, A. G. (2012, April 30). The Québec student strike: From “Maple Spring” to summer rebellion? [Web log post]. Retrieved from http://andrewgavinmarshall.com/2012/04/30/the-quebec-student-strike-from-maplespring-to-summer-rebellion/

Norris, J., \& Sawyer, R. D. (2012). Toward a dialogic methodology. In J. Norris, R. D. Sawyer, \& D. E. Lund (Eds.), Duoethnography: Dialogic methods for social, health, and educational research (pp. 9-37). Walnut Creek, CA: Left Coast Press.

Percy-Smith, B., \& Thomas, N. (2010). A handbook of children and young people's participation: Perspectives from theory and practice. London: Routledge.

Profs contre la hausse. (2012, November 7). Les profs contre la hausse demandent une enquête publique. Retrieved from http://profscontrelahausse.org/communiques/les-profs-contrela-hausse-demandent-une-enquete-publique/

Radio-Canada. (2012, June 7). Grève étudiante et communications à l'ère d'Internet. RadioCanada. Retrieved November 15, 2012, from http://www.radio-canada.ca/sujet/Droitsscolarite/2012/04/03/001-etudiants-reseaux-sociaux-.shtml

Sawyer, R. D., \& Norris, J. (2012). Why duoethnography? Thoughts on the dialogues. In J. Norris, R. D. Sawyer, \& D. E. Lund (Eds.), Duoethnography: Dialogic methods for social, health, and educational research. Walnut Creek, CA: Left Coast Press.

Sciencetech Communications. (2012, June 4). The Québec student conflict. Retrieved December 6, 2012, from http://www.slideshare.net/fullscreen/Guilhaumon_huguette52/correctedstudent-analysis/1

Seymour, R. (2012, Sept 7). Québec’s students provide a lesson in protest politics. The Guardian. Retrieved from http://www.guardian.co.uk

Simpson, J. (2012, May 25). In a province of sacrifice, a few pursue privilege. The Globe and Mail. http://www.theglobeandmail.com/commentary/in-a-province-of-sacrifice-a-fewpursue-privilege/article4209763/

Somerville, M. (2012, June 3). What is happening in Québec. The Ottawa Citizen. Retrieved from http://www.dianaswednesday.com/2012/06/margaret-somerville-what-is-happeningin-quebec/ 
International Journal of Child, Youth and Family Studies (2013) 3.1: 444-463

Sorochan, C. (2012). The Québec student strike - A chronology. Theory and Event, 15(3). doi: 10.1353/tae.2012.0030

Therrien, R. (2012, May 25). Media outlets under close monitoring. Le Soleil. Retrieved from Translating the printemps érable website:

http://ranslatingtheprintempserable.tumblr.com/post/23928967235/media-outlets-underclose-monitoring-le-soleil

Thomas, N. (2009). Children, politics and communication: Participation at the margins. Bristol, UK: Policy Press.

Translating the Printemps Érable. (2012, May 25). An open letter to the mainstream English media. Retrieved from http://translatingtheprintempserable.tumblr.com/post/23754797322/an-open-letter-to-themainstream-english-media

United Nations. (1989). Convention on the rights of the child. New York: UN General Assembly.

Villarruel, F. A., Perkins, D. F., Borden, L. M., \& Keith, J. G. (Eds.). (2003). Community youth development: Practice, policy, and research. Thousand Oaks, CA: Sage.

Warner, A., Langlois, M., \& Dumond, C. (2010) Voices from youth action teams: Creating successful partnerships for community action. In W. Lind, A. Sammel, \& L. Goulet (Eds.), Effective practice of adult-youth engagement in social and environmental justice (pp. 95-108). Rotterdam: Sense Publishers.

Wyatt, N. (2012, June 18). Social media making it easier to organize student protests, get message out. Huffington Post Canada. Retrieved November 14, 2012, from http://www.huffingtonpost.ca/2012/06/18/social-media-making-it-ea_n_1604792.html

Wong, N. T., Zimmerman, M. A., \& Parker, E. A. (2010). A typology of youth participation and empowerment for child and adolescent health promotion. American Journal of Community Psychology, 46(1/2), 100-114. doi: 10.1007/s10464-010-9330-0

Wyn, J., \& White, R. (2000). Negotiating social change: The paradox of youth. Youth \& Society, 32, 165-183. doi: 10.1177/0044118X00032002002

Zeldin, S., Camino, L., \& Calvert., M. (2007). Towards an understanding of community governance: Policy priorities and research directions. Análise Psicológica, 1 (XXV), 7795.

Zeldin, S., Christens, B. D., \& Powers, J. L. (2012). The psychology and practice of bridging generations for youth development and community change. American Journal Community Psychology, 51(3/4), 385-397. doi: 10.1007/s10464-012-9558-y 